\title{
The Contribution of Ethiopian Orthodox Tewahido Church in Forest Management and Its Best Practices to be Scaled up in North Shewa Zone of Amhara Region, Ethiopia
}

\author{
Abiyou Tilahun ${ }^{1, *}$, Hailu Terefe ${ }^{1}$, Teshome Soromessa ${ }^{2}$ \\ ${ }^{1}$ Department of Biology, College of Natural Science, Debre Berhan University, Debre Berhan, Ethiopia \\ ${ }^{2}$ Department of Environmental Science, Science faculty, Addis Ababa University, Addis Ababa, Ethiopia
}

Email address:

abiytila22@gmail.com (A. Tilahun)

\section{To cite this article:}

Abiyou Tilahun, Hailu Terefe, Teshome Soromessa. The Contribution of Ethiopian Orthodox Tewahido Church in Forest Management and Its Best Practices to be Scaled up in North Shewa Zone of Amhara Region, Ethiopia. Agriculture, Forestry and Fisheries.

Vol. 4, No. 3, 2015, pp. 123-137. doi: 10.11648/j.aff.20150403.18

\begin{abstract}
This research was conducted in selected moasteries of Ethiopian Orthodox Church (EOTC) in North Shewa zone. The main objective of the study is to identify main constraints which hinder the society to learn from religious instituions and apply the best practices and habit of experiences on forest conservation. Accordingly six monasteries were selected at different altitudes and sites purposively. Once the study forest areas were identified, 10 X $10 \mathrm{~m}$ quadrats were laid systematically in the forests for vegetation sampling. For the socioeconomic survey, 112 individuals were selected. Moreover, focus group discussion and key informant interviews were employed. Church forests enveloped in this study have an area ranging from 1.6 ha to 100 ha. The total number of species and families in each of the six churches ranged from 17 to 60 and 15 to 39 respectively. Different regeneration status was revealed from the height and diameter class distribution for some of the woody species. The height and diameter class distributions for all individuals in each studied church showed that the forests are at different secondary stages of development. The classification of the species group by ordination techniques showed the differentiation in species group types has a strong relationship with altitude. These church forests didn't come to exist just by chance. Results indicated that it is by the commitment of the church based on strong theological thoughts and biblical basis. It was found that the local community respects and protects church forests, and considers the church as a central institution and platform. However, the community is not strongly committed to adopt forest management culture of the church due to: 1) the church leaders didn't teach more to their followers to plant trees and to transfer the knowledge; 2) limited knowledge of the community about the benefits of forests to their livelyhood. 3), In general, the result of this study revealed that, forests conserved by EOTC and its tradition provide an opportunity to establish insitu and exsitu conservation sites for forest resources. They also have greater prospects in implementing forestry conservation, development, research and education programs with some avoidable threats and constraints for which recommendations were presented. Hence, it will be worthy to include the church and mosque communities when delivering trainings and sharing responsibilities in aforestation programes.
\end{abstract}

Keywords: Monasteries, Indigenous Knowledge, Natural Forest, Conservation, Sustainability

\section{Introduction}

\subsection{Background}

Forests have multidimensional functions and uses to mankind and other living organisms. They play indispensable roles in the life support systems on our planet. However, due to rapid population growth and natural factors the existing natural forests depleted in Ethiopia and brought significant decline in their biodiversity to the extent that some species are on the verge of local extinction. The problem of deforestation and loss of biodiversity is more pronounced in the Central highlands of Ethiopia, particularly in the North Shoa Zone, where forests are downscaled to patches and strips on the tops of hills and heads of streams. As a result, very little of the natural forest of the Central Ethiopian highlands remains today. The deterioration of natural resources not only destroys the environment, but also undermines the very foundation on which economic growth and long-term prosperity depends (Tadesse Woldemariam, 1998). In such devastated areas, 
conserving and maintaining species diversity has been a very challenging task. The only areas where one can observe trees in Central Ethiopia are in the surroundings of churches. These patches of natural forest have survived as a result of the traditional conservation effort of the Ethiopian Orthodox Tewahido Churches (Yeraswork Admassie, 1995). These forests are still sanctuaries of many plant and animal species that have almost disappeared in most parts of northern Ethiopia (Alemayehu Wassie, 2002).

In north Shewa, The Ethiopia Orthodox Tewahido Church has about 406,706 followers, 1800 Churches and 27,980 Priests. The church has a long history of conservation of forest resources arround the churches. Church compounds are serving as conservation sites and hot spots of biodiversity, mainly indigenous trees and shrubs of Ethiopia, which, in turn, give prestige to the religious sites (Alemayehu Wassie et al., 2005).

These church forests, however, are threatened because disturbances such as cutting, grazing, droughts, and fires occur at increasing intensity and frequency. Environmental sectors promote restoration (Yeraswork Admassie, 1995), but the current results suggest that area closure alone cannot restore the original species composition and diversity of the natural ecosystem, such as encountered in some larger church forests. Church forests still harbor a large number of indigenous forest species and at the same time conserve the soil and microclimate. The forest and their species could be used as new sources of regeneration (including via their soil seed banks).

\subsection{Religious Institution and Their Culture of Forest Conservation}

Many tree species surrounding religious areas have relationship with the term sacred groves in most literature. The tradition of the sacred grove is well known in Ethiopian tradition in the experience of traditional religion as the Oromo sacred Adbar or in the clump of trees that customarily envelope the Debr (Bahru Zewde, 1997). Sacred groves are smaller or larger ecosystems, set aside for religious purposes. The origin of sacred groves can be attributed to the slash and burn system of agriculture, where several forests patches was left standing around farmlands. These groves came to be institutionalized as centers for culture and religious life. Taboos and social sanctions protect the sacred groves from deterioration due to human interference. These habitat patches may be the only primary forests remaining locally. Several endemic and endangered species have been recorded from sacred groves. Sacred groves, which form in situ conservation sites and act as a refuge for species, are becoming ecologically important in the light of the current rates of deforestation and species loss. They buffer against the depletion of genetically adapted local variants and overall biodiversity in a region. They can serve as important recruitment areas to surrounding ecosystems. Sacred groves are of great economic significance too (Alemayehu Wassie, 2002).

The doctrine of the religions behind those sacred groves may vary but ultimately the experience of conserving trees for religion purposes is apparent worldwide. Thus, trees not only meet the economic and ecological needs of the people, but also form an integral part of their culture and spiritual tradition (Yeraswork Admassie, 1995).

The Ethiopia Orthodox Tewahido Church has long history of planting and conserving tree species. Church compounds are the monasteries of trees and other biodiversity resources where one can animate trees escaped from being destroyed forever under the shelter of the church value and esteem. Many indigenous trees and shrubs destroyed completely over the last century, are still found standing in the compounds of rural churches (Taye Bekele, 1998). The area of forest cover preserved by the Ethiopian Orthodox churches in some parts of the country has been declined and found in patches. These patches of forests are used as sources of seeds for raising seedlings in nurseries (EFAP, 1996).

Church compounds are serving as in situ conservation and hot spot sites for biodiversity resources, mainly indigenous trees and shrubs of Ethiopia, which in turn give prestige for the religious sites. As a result, these forests are sanctuaries for different organisms ranging from microbes to large animals, which will have almost disappeared elsewhere. Historically, most of the church forests was destroyed and burned with the churches and other precious heritages by the anti-Christian expedition led by Ahmed Ibn Ibrahim also called 'Gragn' meaning 'left handed' in the beginning of the 16th century. After 'Gragn' has been killed in 1543, most of the churches and monasteries were reconstructed together with their forests (Aymro Wondmagegnehu and Motovu, 1970). In the process of nationalization of private properties during the socialist regime the EOTC was left without its land holdings, including the forests, which have been preserved for centuries. The fate of those forests was ruthless exploitation and destruction, which in turn brought a severe reduction in biological diversity and ecological imbalance as well.

\section{Materials and Methods}

This study was conducted in North Shoa Zone, Amhara Region. The topography comprises uneven and ragged mountainous highlands, extensive plains and also deep gorges and cliffs. This features provided the zone with spectacular scenic beauty and stunning views across the Yifat and great rift valley up to the Awash river in the Afar ( Zelalem Tefera, 2001).The rainfall is characterized by a bimodal distribution with the major rainy season being from June-August and the 'Belg' from March-May. The annual average rainfall varies between $400-700 \mathrm{~mm}$ and the annual average temperature ranges between $-8-35.7^{\circ} \mathrm{C}$. 


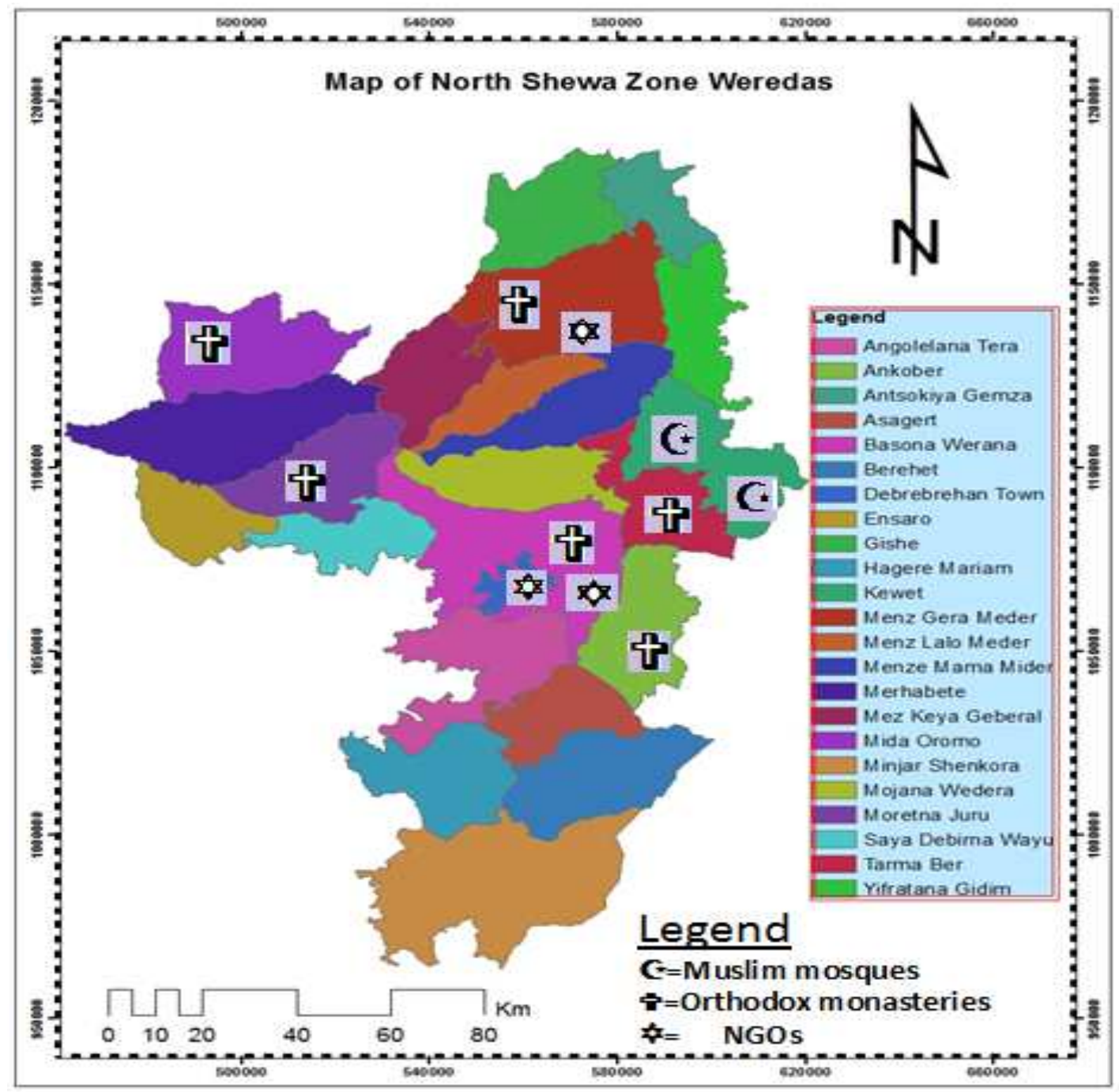

Figure 1. Map of the study areas.

Selection of study sites was based on representativeness of ecological and administrative regions, Emphasis on old sites and sites of religious significance, Site accessibility and feasibility for the study and Sites with high conservation value and mixture of sites with and without threats. Six monasteries of Ethiopian Orthodox Tewahido church were selected purposively from six district of North Shoa Zone for the socio-economic survey as a study site (Getahun Kassa and Eskinder Yigezu, 2015):

I. Washa Debre Medihanit Abune Melke tsiediek monastery in Mida Woremo District

II. Debre Bisrat Abune Zena Markos Monastry in Moret and Jiru District

III. Debre Menkirat Mitak Amanuel Monastery in Ankober and Basona Worena District

IV. Debre Hail Kidus Rufael church in Menz Gera District

V. Debre Menkirat Gashu Amba Merkoriwes in Tarmaber District

VI. Debre Kerbe Dagmawi Goligota in Basona werana District

\section{Methods}

The participatory rural appraisal (PRA) method was employed to generate the socio-economic information and government intervention following Martin (1995) and Cunningham (2001). Primary data was collected by semi-structured, key-informant interviews and group discussion (Muluken Mekuyie, 2014). Descriptive statistics were used to analyze the data included percentages and frequencies. Based on the participatory rural appraisal result analysis on the traditional conservation, natural regeneration and current status of forest resources was drawn. All the stakeholders such as District office of agricultural experts, administrative bodies, EOTC representatives, Church scholars, community elders, NGOs were discussed on the practices of the Church on biodiversity conservation. Semi structured questionnaires was pretested before use on a wider scale, and some improvement was made to the questionnaire. The results were presented in the forms of tables and graphs (Siboniso M. Mavuso, Absalom M. Manyatsi, and Bruce R. T. Vilane, 2015). 


\section{Result}

\subsection{Socio-economic Survey of Ethiopian Orthodox Tewahido Church}

\subsubsection{Participatory Rural Appraisal}

Initial discussion was held with selected District agricultural bureau representatives and religious leaders to explain the purpose of the study and to get permission in order to conduct the study in the area (Elias Endale, 2003).

Based on the information generated from the discussions at various levels, key participants were selected. The selection criteria was their long residence, better knowledge of environment and natural resources and ability to articulate the functioning of religious institute on the forest. The extraction of information on forest status was made by using Participatory Rural Appraisal (Abeje Eshete, et al., 2005).

A total of 112 respondents, of which $94(83.9 \%)$ male and the remaining $18(16.07 \%)$ female were involved in the study. $71(63.39 \%)$ of the respondents were from EOTC Monks and clergies, 13(11.6\%) from Muslim Imams and Sheks, 6(5.35\%) from NGOs, $12(10.7 \%)$ from community leaders who live in the area more than 30 years, $10(8.9 \%)$ from kebele and District agricultural expert and administrative bodies (Fig. 2).

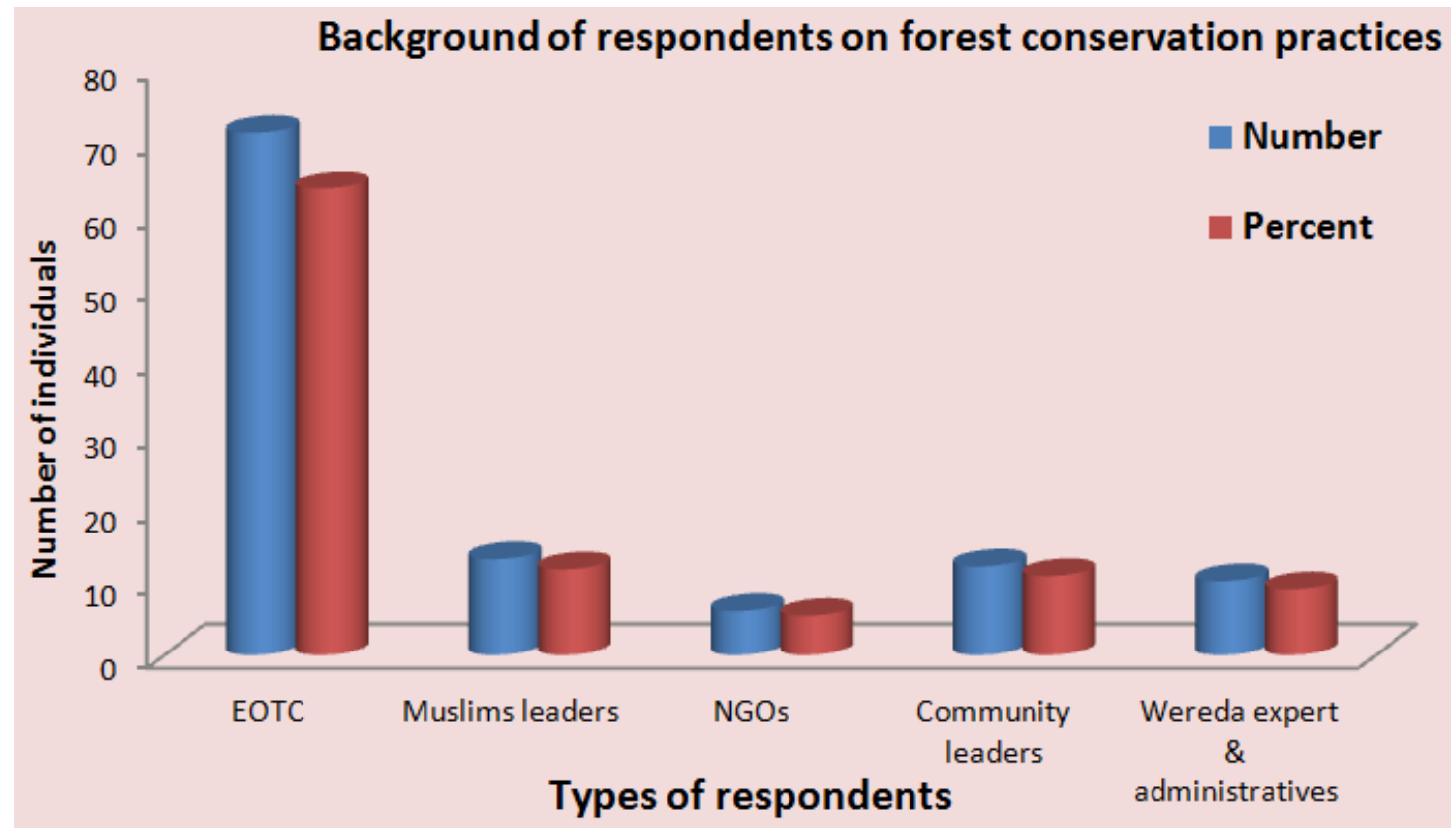

Figure 2. Discussant stakeholders in forest conservation, 2005 E.C.

Group discussions with multiple stakeholders and Participatory Rural Appraisal which allow us to explore a range of concerns and raise awareness on the resources were the main methods to collect the information. During the discussions an attempt was made to encourage the stakeholders in such a way that their cooperation is of great benefit to themselves and the country. The selection of appropriate time and location were encouraging for the participants of the group discussion.

In these discussion and participatory rural appraisal, information gathering were focused on indigenous knowledge of each group in relation to methods of sustainable use and conservation and giving priority for tree species, showing very low regeneration potential. Pair-wise ranking technique were used to identify and make comparison among plant species identified for different uses such as construction, farm implements, beehive making, bee fodder, fuel wood, woodcarving, medicinal use and others. In addition, the most threatened species were also identified based on the number of dead standings, number of stumps, seedlings and saplings.

Participants thought that forest protection and forest genetic resource conservation seems to be the duty and responsibility of the monastery and the government alone. But the efforts of EOTC monastery to protect their natural forest against irresponsible deforestation are indispensible.

Ninety eight percent (110) of the respondent believes that religious institutions have indigenous knowledge and practice of forest resources conservation but, the local communities cannot exploited the experience to apply on their surrounding due to different constraints. Eighty one percent(91) respondent believes that this conservation practice is gradually decline and is being eroded in the near future because of government administrative complexity, $95 \%$ of the respondent agreed that, lack of education to the young generation by the religious leaders about forest conservation and population growth and farm land expansion(99.5\%) (Table 1). 
Table 1. Percentage of the respondent on the forest conservation practice in North Shewa zone.

\begin{tabular}{|c|c|c|c|}
\hline Discussion points/items & Agree & Disagree & None \\
\hline There is religious institution that has long history of planting, protecting and preserving of trees species & $99 \%$ & $1 \%$ & $0 \%$ \\
\hline This practice is still operational in the institution at your locality & $23 \%$ & $77 \%$ & $0 \%$ \\
\hline \multicolumn{4}{|l|}{ The cause for the decline of forest conservation practices } \\
\hline - Government involvement in the traditional practice and territory & $88 \%$ & $12 \%$ & $0 \%$ \\
\hline - Decline the acceptance of religious leaders on resource conservation by the new generation & $62 \%$ & $38 \%$ & $0 \%$ \\
\hline Local community exploit and apply the best practice of religious institution & $7 \%$ & $93 \%$ & $0 \%$ \\
\hline \multicolumn{4}{|l|}{$\begin{array}{l}\text { Reasons, why local people cannot learn and apply such practice in government owned and private forest } \\
\text { resources }\end{array}$} \\
\hline \multicolumn{4}{|l|}{ 1. Poverty } \\
\hline - $\quad$ Lack of grazing land for their domestic animals & $98 \%$ & $2 \%$ & $0 \%$ \\
\hline - Illegal agricultural land expansion & $95 \%$ & $5 \%$ & $0 \%$ \\
\hline $\begin{array}{l}\text { 3. Poorness interms of knowledge transfer to the generation about the experiences of EOTC on forest } \\
\text { conservation }\end{array}$ & $68 \%$ & $20 \%$ & $12 \%$ \\
\hline $\begin{array}{l}\text { There is an effort to incorporate the best practice by the government and agricultural experts with the modern } \\
\text { conservation and management strategies }\end{array}$ & $17 \%$ & $83 \%$ & $0 \%$ \\
\hline $\begin{array}{l}\text { It is possible to integrate the religious conservation and management practice with modern conservation } \\
\text { system to rehabilitate degraded areas and sustain the remaining few natural forests in the zone }\end{array}$ & $94 \%$ & $6 \%$ & $0 \%$ \\
\hline
\end{tabular}

Table1. shows that $99 \%$ of the participant conclude that religious institution has long history of planting, protecting and preserving of trees species. But such interesting nature conservation habit is not sustainably managed due to factors like anthropogenic pressure, farm expansion, charcoal production, grazing by domestic animals, low awarness on the forest and alien invasive species (Figure 3). The local people, agricultural expertise, governmental representatives have little effort to learn and apply best practice of surrounding monastery on forests and other natural resources conservation.

\subsubsection{Uses of Forest Plant Species Identified by the Local Communities During PAR}

The forests grown in monasteries are considered as sacred because they are growing in God's compound and besides that they are symbolic to the presence of angels guarding each church, surrounding it. Besides the spiritual aspects, trees in monasteries provide several material benefits. They are sources of fuel wood that is required for services of the church; they provide shade from the scorching sun for the clergy and the laity during mass and religious festivals and the stems of the standing trees give support to individuals during prayers. Besides, the trees add aesthetic value to the church. As it is listed in Table 2, in monasteries, forests play other important roles in addition to the aforementioned services. Hermits and monks use the forests as praying sanctuary and also feed on the leaves, fruits and other parts of the wild plants. Conservation of forest around monasteries helps to give grace for the monasteries, serve as traditional learning and teaching under the shade of trees, resting places/sanctuaries for saints, provide sweet aroma to the church and trees around churches symbolise the fact that God created Adam and and Eve and placed him in Eden. The participants point out the Material benefits of trees to local people and monastery community identified during
PRA.They have grouped in to four basic uses: I. Provisioning Services (Food, Fiber and Fuel, Genetic Resources, Biochemicals, Construction materials for churches), II. Regulating Services (Invasion resistance, Herbivory, Pollination, Seed dispersal, Climate regulation, Pest regulation, Disease regulation, Natural hazard protection, Erosion regulation, Water purification), III. Cultural Services (Spiritual and religious values, Wood for making sacramental objects such as drums, crosses and support sticks for church services, Knowledge system, Education / inspiration, Recreation and aesthetic value, National heritage) and IV. Supporting Services (Primary production, Provision of habitat, Nutrient cycling, Soil formation and retention, Production of atmospheric oxygen, Water cycling and Climate balance).

\subsubsection{Threats and Major Causes of Forest Depletion}

Based on PRA discussion, collected data and physical observation threatened tree and shrub species in the considered study site were identified. Almost all of the participants identified that, Juniperus procera as most threatened species. Hagenea abyssinica was identified as second most threatened species followed by Podocarpus falcatus and Olea europaea sub sp.cuspidata. Both species are highly preferred for woodcarving, local construction and fuel wood. Ekebergia capensis and Pittosporum viridiflorum which is used for timber, woodcarving and fuel wood, was identified as third most threatened tree species by both groups. The different choice of second most threatened tree species by men and women shows that both groups have got different perspective in examining and interpreting problems in a different way based on their own experience and roles in society. Therefore, it is important to accommodate the ideas and experiences of all stakholder groups to come to an effective and practical forest conservation mechanism. 


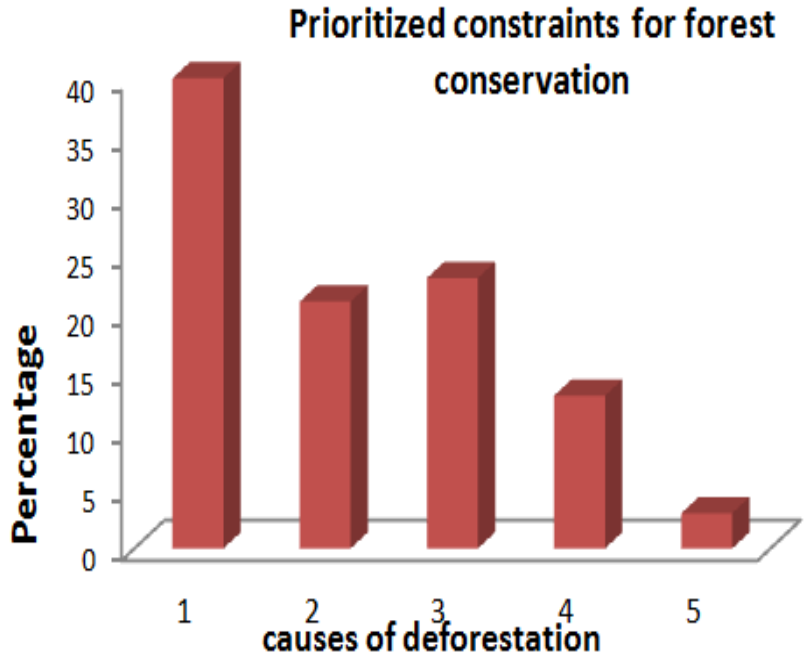

Figure 3. Major causes of deforestation and losses of biodiversity.

Key: $(1=$ Anthropogenic pressure, $2=$ Farm expansion and Charcoal production, $3=$ Grazing by domestic animals, $4=$ Low awarness on the forest and $5=$ Alien invasive species.

Source: Participants of the PRA discussion in forest, 2005 E.C.

\section{(i). Anthropogenic Pressure}

High human pressure with negative impact on the natural resources and biodiversity richness weighs on the forest today: intensive human impact from livestock grazing and fuel wood and timber use. As figure 3. describes, Anthropogenic pressure accounts the largest share for forst destruction followed by grazing by domestic animals and then farm expansion and charcoal production. Human pressure is highly intesified in Mitak Amanuel and Abune Zena Markos natural forest. Farm expansion is also the main problems of Mida Abune Melketsiediek monastery forest.

\section{(ii). Invasive Species}

The destructive impacts of invasive alien species was identified in Kewet,Yifratana Gidim districts towards Afar and Dessie. Among the invesive species lantana camara was replacing all of the shruby plant species with a very rapid rate.This is intensified to the right of Tarmaber to Menz Guassa plains and terrains from Shewarobit to Ataye, in these areas it quickly takeover valuable grazing lands and most of the mountainous areas which was covered by many indigenous herbs and shrub species.

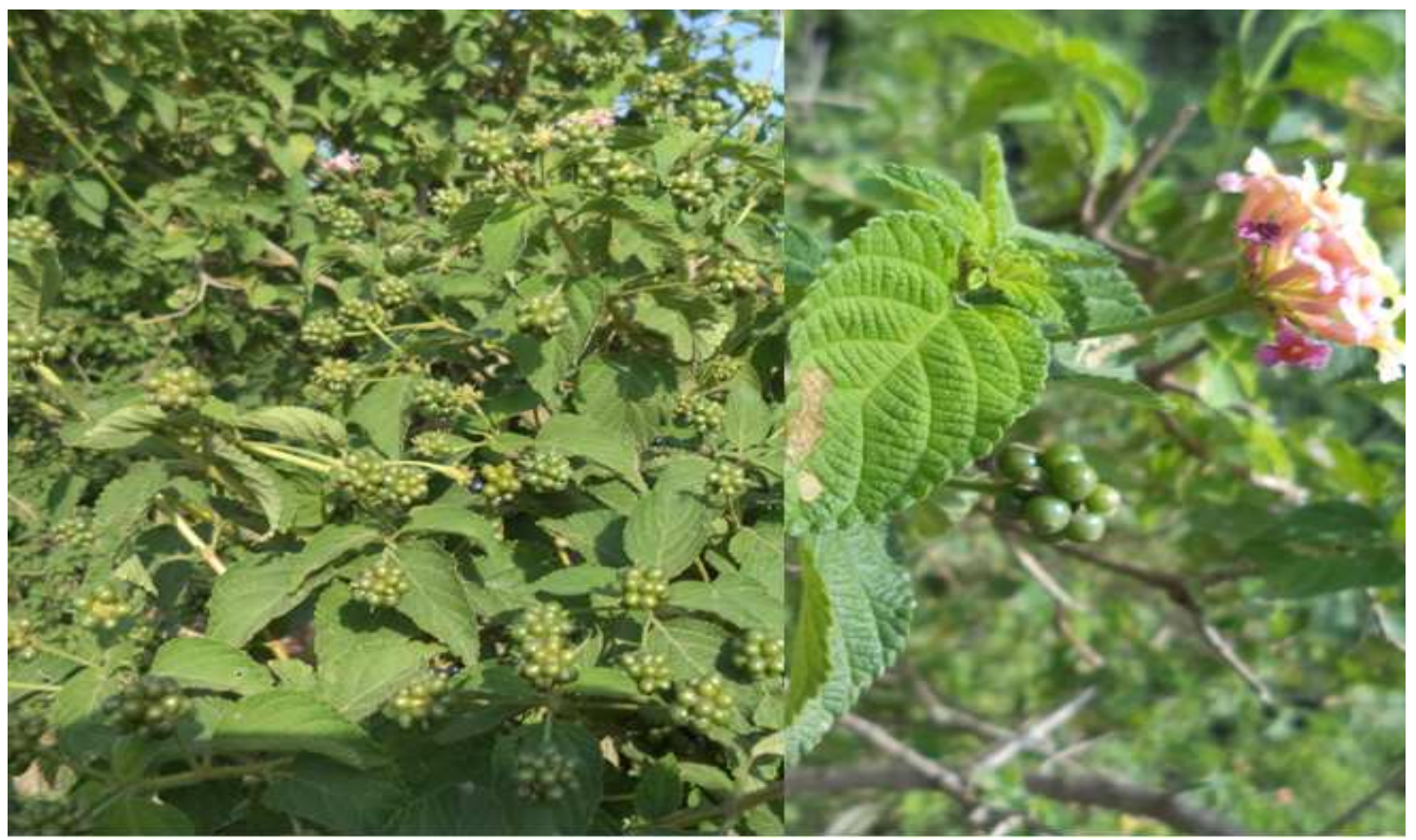

Plate 1. Photo by Abiyou Tilahun and Hailu Terefe, 2005E.C.

\section{(iii). Over Grazing by Livestock}

Our results confirmed that livestock grazing is the major factor limiting seedling establishment and seedling survival and growth in church forests(Table 3). Studies in Ethiopian highlands showed that heavy grazing pressure significantly increased surface runoff and soil loss and reduced infiltration capacity of the soil which in turn undermines suitability of sites for germination (Mwendera and Mohamed Saleem, 1997). This suggests that the effect of grazing on seedling survival and growth depends on the species. In general controlling livestock grazing is of paramount important for both the internal regeneration of church forests and for restoration of the degraded surroundings.

Table 2. Localy threatened tree species identified by stakholders in the PRA.

\begin{tabular}{lll}
\hline Rank & Identified species & Percentage of priority \\
\hline $1^{\text {st }}$ & Juniperusprocera & 65 \\
$2^{\text {nd }}$ & Hageneaabyssinica, & 21 \\
$3^{\text {rd }}$ & Oleaeuropaeasubsp.Cuspidata & 11 \\
$4^{\text {th }}$ & Podocarpusfalcatus & 2 \\
$5^{\text {th }}$ & Ekebergiacapensis & 1 \\
\hline
\end{tabular}

Source: Participants of the PRA discussion, 2005 E.C 
According to the participants, population growth, grazing by domestic animals farm expansion and natural forest fire (lightening) are the major causes of the depletion of Religion natural forest, in this order of importance (Table.2). All the problems facing natural forest are strongly interrelated to each other.

\subsection{Analysis of the Study Areas}

\subsubsection{Debre Medihanit Abune Melketsedik Monastery in Mida Woremo District}

Washa Debre Medihanit Abune Melketsedik monastery is found in Mida weremo District, and was built in the $14^{\text {th }}$ Century in the name of Abune Melke tsiediek. It is located at $10^{0} 14^{\prime} 19^{\prime \prime} \mathrm{N}$ and $039^{\circ} 05^{\prime} 07^{\prime \prime} \mathrm{E}$ at altitudinal range of the forest varies between 2299 to $2580 \mathrm{~m}$ a.s.l. The mean annual minimum and maximum temperature of the area is $16^{\circ}$ and $30^{\circ} \mathrm{C}$ respectively. The mean annual rainfall of this area is $1427 \mathrm{~mm}$. From this information it could be concluded that these monastery forests lie within the moist "Weina Dega" Climatic Zone Classification of Ethiopia. The actual forest covers 45 ha. The most important both religional and cultural features are the Monastery and homesteads of the Mida weremo people particular interest even in the national context, this is due to its thousands of old intact mummy. Various churches in the area have old and extremely valuable artefacts, which are of interest to tourists.

Woody species composition:The monastery has a very large and old Weira (Olea euroapea sub sp cuspidata) trees boardered by farmlands in the South,North and West are large cliffs in the East and plain in the South East.The upper canopy of these forests was dominated by Albizia schimperiana, Millettia ferruginea, Croton macrostachyus, Celtis africana and podocarpus falcatus. Smaller trees of the forest included Ackocanthera schimperi, Dombeya torrida, Olea europaea sub sp cuspidata, Allophylus abyssinicus, Ekebergia capensis and Pittosporum viridiflorum. The shrub layer was dominated by Budleja polystachya, Carissa spinarum, Euclea schimperi, Maytenus arbutifolia and Calpurnia aurea.

Threats:The monastery forest has faced much pressure from the local people. Areas other than owned by monastery are totaly degraded and gradually eroding the edges of the monasteries particularly that of western and Northern part of the monastery.

\subsubsection{Debre Bisrat Abune Zena Markos Monastry in Moret and Jiru District}

The Monastery is found in Moretena Jiru district, and was built $12^{\text {th }}$ century in the name of Abune Zena Markos. It is located at $09^{0} 52^{\prime} 05^{\prime \prime} \mathrm{N}$ and $039^{\circ} 04^{\prime} 29^{\prime \prime} \mathrm{E}$ at an altitude of 2866 m.a.s.l. The actual forest area covers 23 ha. The monastery forest resources are declining in both quantity and quality. The natural forest is composed of mainly over-mature trees with poor prospect for regeneration. The destruction of the forest aggravated soil erosion to the southern part the District.

Woody species composition: The characteristic species of Abune Zena markos Monastery natural forest are Juniperus procera and Olea europaea ssp cuspidata. The density of these species having DBH above $10 \mathrm{~cm}$ is 130,28 and 20 stems/ha respectively. Maytenus arbutifolia is the main under-storey species and also the regenerating species in the natural forest. There are 16 indigenous tree and shrub species each representing different families. This forest also contains relatively large plantations of Cupressus lusitanica and Eucalyptus globulus. The complete floristic list of indigenous tree and shrub species of Abune Zena markos monastery forest is given in Appendix 1. There are old aged huge tree species more than 2000 years old planted by St. Abune Teklehaimanot which can be considered as the key stone species for other organisms, especially Juniperus procera and Olea euroapea sub sp cuspidata.

Threats: The major threats on this forest are mainly from human pressure for wood products and for expansion of agricultural land. There is severe illegal cutting of trees for fuel wood and construction purposes. The local people are settling in the forest and converting the forest in to agricultural land. Grazing by domestic animals especially, cattle, goats and sheep in the forest are common practice of the local community.

\subsubsection{Debre Menkirat Mitak Amanuel Monastery in Between Ankober and Basona Worana}

This monastery is found at the boarder of both Ankober and Basona werana District and built in the first half of the $16^{\text {th }} \mathrm{C}$ in the names of St. Amanuel, St. Teklehaimanot and St. Gebriel . It is located at $09^{\circ} 34^{\prime} 27^{\prime \prime} \mathrm{N}$ and $039^{\circ} 41^{\prime} 07^{\prime \prime} \mathrm{E}$ with an altitude of 2837 m.a.s.l. The actual forest area is 78 ha surrounding a sloping hill. The forest has become a small refuge for a large variety of fauna and flora and numerous native species. The forest is an important source of both seeds and seed dispersers vital to traditional shifting cultivation practices, and of herbs for local medicinal, social, and religious purposes.

The forest has been protected and managed by religious leaders and villagers for centuries. When it was first demarcated, unwritten regulations were put in place by the Monastery monks and priest and other village leaders regarding forest land use in and around the forest. Over time, some of these rules have been amended to ensure their continued relevance and effectiveness. Today, they protect the original forest by regulating the behavior of the people of area and to some extent of the residents of neighboring communities are violating this regulation. All forms of deforestation and grazing in the around the forestare prohibited. Entrance into the forest area is permitted only during annual Holy days.

Shortage of fuelwood, farm implements, and grazing lands exist in and around the forest despite the care evident in the protection of the area. Women walk up to 5 kilometers to collect fuel wood; one full day of searching is commonly required to gather enough fuel wood for three days. Residents around the monastery know they could make use of the forest resources in the forest, but their faith and their forest management regulation prohibites them from doing so.

Woody species composition: The upper canopy of this 
forest was dominated by characteristic species such as Juniperus procera and Olea europaea sub sp cuspidata. Smaller to medium sized tree species of this forest, which posses the middle canopy, included Croton macrostachyus, Rhus glutinosa, Nuxia congesta, Pittosporum viridiflorum and,
Ekebergia capensis. The shrub layer is dominated by Ross abyssinica, Calpurnia aurea, Carissa edulis, Dodonaea angustifolia, Euclea schimperi, Maytenus addat, Maytenus arbutifolia, Myrsine africana, Osyris quadripartita, and Premna schimperi.

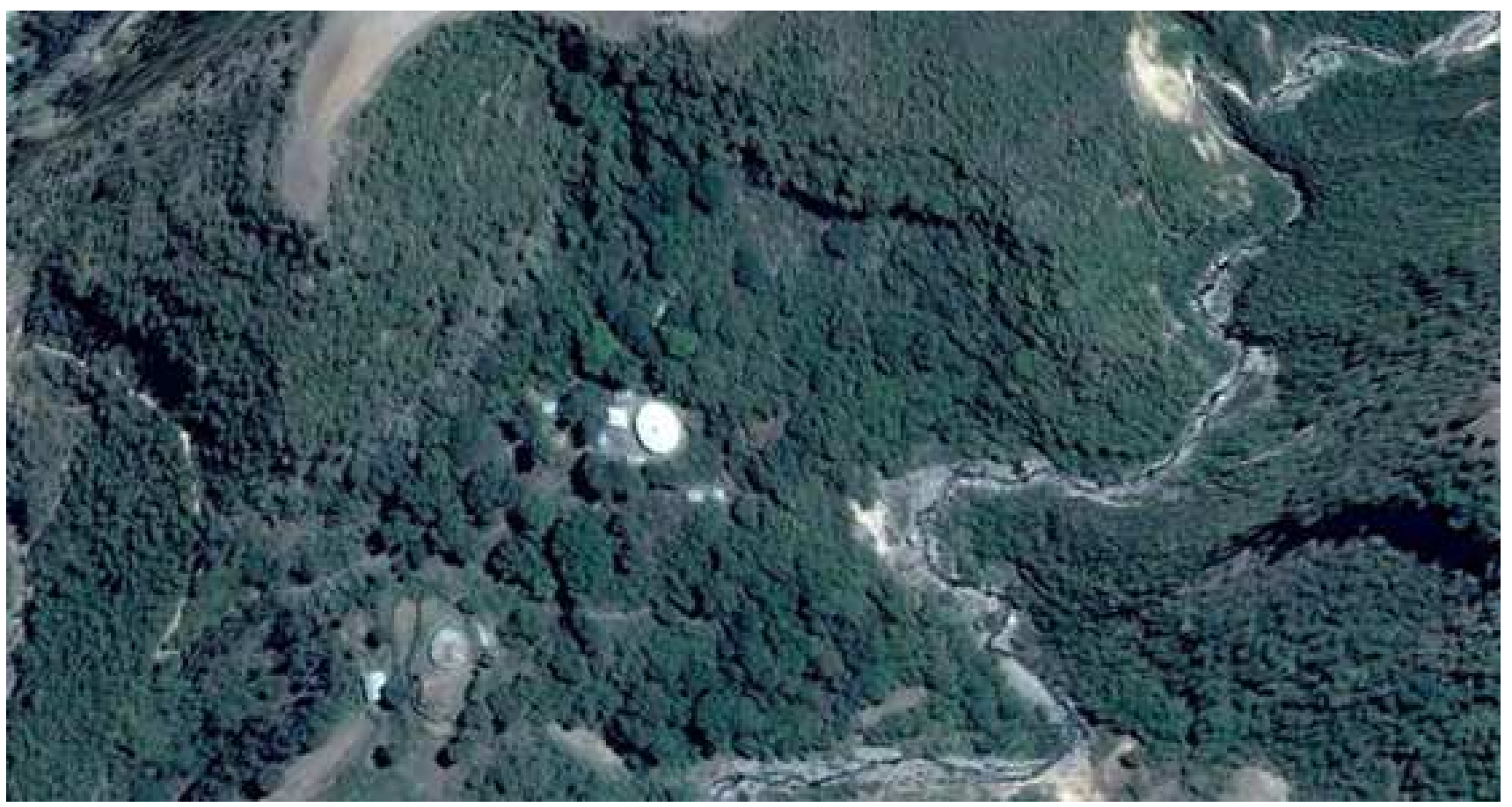

Plate 2. Well protected part of Mitak Amanuel forest Source from Google earth of imagery date 1/29/2014.

Threats: The major threat to this forest is mainly from human pressure for wood products. There is severe illegal cutting of trees for plumbering, fuelwood and construction. Most of the surrounding local people depend on the forest for their living particularly by selling timber for house construction. The Mitak Amanuel Monastery forest is found in an area where there is a serious shortage of wood for energy source and other uses. According to the monastery people forest products are transported all the way to Ankober, Debele and Debre Birhan. Deforestation rate is very high and the kebele administration and the concerned bodies have not taken appropriate measures. There is a fear that the monastery forest can be lost within a short period of time unless drastic measures are taken.

\subsubsection{Debre Hail Kidus Rufael Church in Menz Gera District}

This church is found in Menz Gera District, and was established in 1924 by Atse Be-Ede Mariam as both spiritual and palace. It is located at $10^{\circ} 15^{\prime} 32^{\prime \prime} \mathrm{N}$ and $39^{\circ} 32^{\prime} 24^{\prime \prime} \mathrm{E}$ at an altitude of 2921 m.a.s.l. The actual forest area covers 40 ha. This site is highly encroached by the local and nearby dwellers. According to the church scholars and dwellers, there are two sections of the forest. The inner section, next to the church demarcated by a stone fence, is entirely forbidden for animals while in the outer section of the forest, animals are free to rest under the shade. It is forbidden to cut down trees.

\subsubsection{Debre Menkirat Gashu Amba Merkoriwes in Tarmaber District}

This church is found in Tarmaber District, and was established during the era of Amha Iyesus as spiritual site. It is located at $09^{\circ} 51^{\prime} 52^{\prime \prime} \mathrm{N}$ and $039^{\circ} 50^{\prime} 25^{\prime \prime} \mathrm{E}$ at an altitude of 1947 m.a.s.l. The actual forest area covers 3 ha which is surrounded by farmlands in all direction.

Woody species composition: The upper storey of the forest is non-uniform and non-compact layer of trees like Celtis africana, Juniperus procera and Euphorbia abyssinica. The most dominant trees in the forest are Olea europaea $s u b s p$ cuspidata, Ziziphus mucronata, Terminalia brownii, Syzygium guineense, Rhus glutinosa, Carissa spinarum, Croton macrostachyus, Calpurnea aurea, Euphorbia abyssinica, Opuntia ficus indica, Lippia adoensi, Premna schimperi, Adhatodia schimperiana, Eucalyptus camaldulensis, Euclea schimperi, Pterollobium stellatum, Dodonaea angustifolia and Euphorbia tirucalli. There are significant numbers of species which are very aged and serve as flagship species for more species of animals. Among which Ficus vasta and Juniperus procera are the most dominant. In addition to planed tree plantation by the church administration, there are volunteers who plant trees around the church holdings. Volunteers plant trees that they choose for the purpose of the memory of themselves even after they had gone. For example a passed father called Aba Tariku planted Warka (Ficus vasta) 250 years ago at the front side of the gate where holiday 
celebrations and mass gatherings for various purposes going on today. Everybody call the tree father Tariku's tree. The tree has huge and deep roots, circular canopy with wide branches. It is the grace of the vicinity when seen from distant(Plate .3).
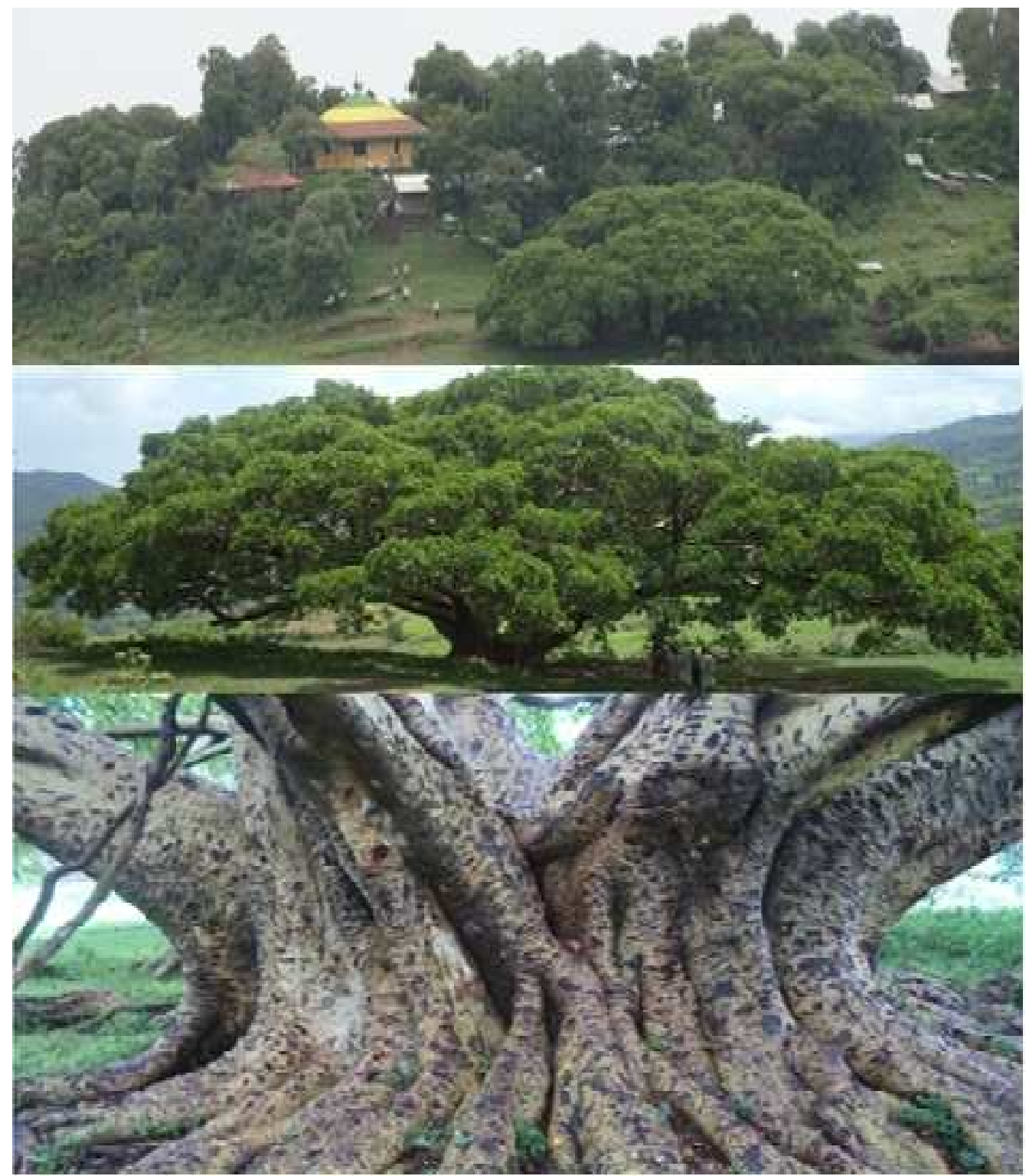

Plate 3. Ficus vasta planted by Aba Tariku 250 years ago, Photo by Abiyou T. and Hailu T., 2005E.C.

The area has relatively low humidity and limited rainfall where there is a prolonged dry season. Forests have diminished due to human interference and have been replaced by bushlands in most areas. Soils have become shallow as a result of soil erosion that has been taking place for centuries.

The church community has comments on the current soil and water conservation and rehabilitation programs of the government. According to the result of PRA, the effort made by the government to reclaim degraded areas and non-productive lands is very good. However, it would be more effective if government give us the training and try to address the people through priests since every farmer is the son/daughter in God of them. Furthermore, the seedlings that are brought to a certain area should be selected seriously for their adaptation to that specific locality.

There is no deforestation practice around the church; so that many aged trees among with the forest diversity are kept for long periods of time. The reason for this, according to the church community, is that people face problems when they cut and take plants. Some people also do not want to cut trees from the church vicinity because of religion honors. Even though those ancient churches with their forest diversity live in the community for centuries, people couldn't learn from them and plantation of indigenous trees around the homesteads of the farmers is not practiced. There are two reasons for this situation in Gashu Amba. First, Church fathers didn't give due attention and advice to their son/daughter in God to plant trees and conserve nature; second, farmers plant Eucalyptus trees for $\log$, construction, firewood and other economical use. They focus mainly on the short term benefits of Eucalyptus than the long term sustainable environment by planting indigenous trees. 


\subsubsection{Debre Kerbe Dagmawi Goligota- in Basona Werana District}

The forest is found in Basona werana with seven killo meter distance in the North from Debre Birhan town. Its geographical location is at $9^{0} 49^{\prime} 23^{\prime \prime} \mathrm{N}$ and $039^{\circ} 27^{\prime} 54^{\prime \prime} \mathrm{E}$ with an altitude of 2,786 m.a.s.l. and has an area of 18 ha forest cover.

Woody species composition: The upper canopy of this forest was dominated by Olea europaea sub sp cusidata, Croton macrostachyus, Allophyllus abyssinicus, Juniperus procera and Eucalyptus globulus. Smaller trees in this forest included Nuxia congesta, Rhus glutinosa and Hypericum revolutum. The shrub layer was dominated by Rossa abyssinica, Calpurnia aurea, Carissa spinarum, Dovyalis abyssinica, Bersama abyssinica, Maytenus arbutifolia, Osyris quadripartita, Maesa lanceolata and Myrsine africana. There were 56 indigenous tree and shrub species representing 31 families. The complete floristic list of indigenous tree and shrub species of Golgota forest is given in Appendix 6.

Threats:Though local people that reside around the forest exert some pressure on the forest for fuelwood and construction wood, it is not as severe as other monastery forests.

\section{Discussion}

\subsection{Expperience of EOTC Forest Conservation Practiceses and the Habit of Government to Apply Traditiona Religious Knowledge}

The main consraints obserbed which hinder to use local ecological knowledge on both the government and locl community were:

\subsubsection{Poverty}

This can be reflected by lack of grazing land for their domestic animals due to agricultural land expansion as a factor of population pressure. The farming community focus on the short term benefits like production of food crops, feed for their livestock and fast growing trees like Eucalyptus tree for construction and fire wood. Hence, the holdings of the farming community including the communal lands are severly degraded and devoid of diverse tree species.

\subsubsection{Lack of Attention to Knowledge Dissemination on Forest Conservation Practices}

The central objectives of religious education is about dogmatic and cannonical doctrine of the church which is about what they are allowed to do and not to do. They know that plant species are bases for the life of human beings in spiritual, medicinal, social, economical, environmenal and ecological perspectives. But there is no more experience and habit of teaching to the followers about conservation. As it is listed in Table $176 \%$ of the PRA participant agreed that there is lack of education about knowledge and best habit transfer to the young generation and natural resources expertise. The monasteric community revealed "nature conservation knowledge transfer" as a constraint practice in the church.
They address their concern that many religious institutional education systems do not value to knowledge transfer. They request cooperation and training from government and outsiders toward their sacred plants conservation and utilization. EOTC monks and clergies recognized the importance of experience sharing among other elders because they believe that this strengthens the conservation habits, instead of emphasizing the differences among religious institutions. They acknowledge the need to disseminate the experiences and knowledge of their ancestors among our peoples.

\subsubsection{Lack of Co Operatiernal Bodies to Monastic Communities}

According to the result of PRA, there should be signed formal agreements between religious organizations and the governmental representatives in terms of respection of organizational structure of monastic community. It is important to maintain the religious institutional arrangements and decision-making processes and avoid the inclination to interfere in some decision-making processes. With respect to participation, the religious community request to be consulted on time and efficiently by the governments and the private sector regarding any action or program that may directly or indirectly affect their vegetation and other resources.

\subsubsection{Gradual Decline of Cultural Integrity of Some Young Generations}

Monastric communities that have strong historical continuity, cultural and spiritual heritage should be supported. These communities are known to preserve, develop, and transmit their innate identity and ancestral territories to future generations as the basis of their continued existence. The church community in accordance with their own cultural patterns spritual belifs and legal systems need recognition and support in order to pass their heritage to the next generation; because contributions to indigenous knowledge and spiritual beliefs can reflect improved conservation efforts. Most of the religious leaders recognize that all members of their community are united because they have a common origin and a spirituality that is founded on love and respect for nature. Their knowledge is practical and collective and is directly linked to people's daily lives. They also acknowledge the respect that they have for their elders as they are the carriers of knowledge and history and they remind them of conserving and preserving their own culture and history. But, by nowadays the young generation is moving to the imported fashions than the domestic and original cultures and spiritual heritages due to unwise utilization of current and global products.

\subsubsection{Lack of Clear Demarkation of Territories of Sacred Sites and Experience Sharing}

According to the result of PRA, the first thing that $95 \%$ of the monastery community mentioned is the importance of demarcation to their survival and that they understand how important it is to live in harmony with nature. They have preserved certain areas within their territories that are sacred, 
such as rivers, caves, lakes, springs, islands, etc. They acknowledge their common history of the loss of territories. For this reason, they think that the land cannot be sold and they request common titles to their lands through presidential decrees or other similar means. They call to all humanity so that together we can preserve nature and avoid water and air pollution, deforestation of our forests, and the indiscriminate exploitation of resources.

\subsection{Major Threats to Church Forests in the Selected Mnasteries of North Shewa Zone}

This study has got experiences of the religious institution as the major contributor for forest conservation and origin of endangered species like Ackocantra schimperi, "etsezewie", "etsehiwot" and etc, in north Shewa. But there are root causes for the loss and destruction of such species in particular and forest resources in general.

Clearing for Agriculture: Conversion of natural forests to agriculture is the greatest threat due to population growth, low productivity of agriculture, unsustainable agricultural systems due to soil erosion.

Unsustainable levels of harvest: Over-harvest of forest products are occurring on a widespread basis leading to deforestation. The main causes are demographic pressures and growing demand, especially urban demand, for firewood, charcoal and other products.

Over-grazing:Overgrazing results in decreased soil cover, increased erosion, elimination of the natural regeneration of plant species and loss of biodiversity. Root causes include demographic growth and lack of incentives for sustainable use

Alien invasive species: are one of the major factors threatening biodiversity resources in north Shewa especially Kewet District. The prominent alien species that cause damage across the country include Parthenium hysterophorus, Prosopis juliflora, Eichornia crassipes and Lantana camara. Lantana camara is becoming a major problem by replacing natural vegetation in to shrubby areas. This problem is intensified from Shewarobit to Kombolicha.

Extreme care is required in the selection of species to be introduced to minimize any impact on native species.

\subsection{Relative Success of the Ethiopian Orthodox Church in Protecting Natural Forest}

\subsubsection{Strong Beliefs of Local People and Religious Leaders}

The small pocket of forest in the monastery is protected primarily because it is the sanctuary of the Monks and nuns. Indeed, it is difficult to isolate the remnant patches of forest-related activity from religious beliefs and practices surrounding the monastery / churches. In the people's minds, the defamation of the forest would dishonor the monk's community and bring misfortune to the offending individual and the community. By protecting the forest, the people of Mitak derive many benefits in addition to the spiritual rewards of serving their faith. The people's strong beliefs in the religion, ensures that only few villagers violate the rules safeguarding the sacred grove; indeed villagers are key to protecting it from non-believers. Community vigilance rather than formal policing is sufficient to enforce the regulations.

\subsubsection{Locally Accepted Protection Guidelines for the Church Forest}

The successful establishment and preservation of the forests trace their roots to informal regulations and practices founded on the spritual worship. For centuries, local people have adhered to specific guidelines that restrict land use in and around the church and have performed activities to secure the forest from human interferences. By respecting the church's privilege in entering the forest, keeping their compounds, farms, and livestock out of the church forest and protecting the holy site from fires and other threats, residents have a stake in local adherence to these rules.

\subsubsection{Regional Collaboration and Support}

Church forests are becoming increasingly important in the area, adding strength to church representative's beliefs and protection efforts. As religious beliefs, small communities are weakened and their pressures on forest resources increase, natural forests in many communities are encroached upon and forests are degraded. This is especially the case in areas Mitak Amanuel, Abune Zena Markos and Gashu Amba Qidus Merkorios due to the proximity of the forest to urban centers where religious systems and commonly-held natural resources are exceptionally vulnerable to modernization and large-scale development. Such forest areas are threatened by encroachment, trampling or destruction and most local resource base has been so degraded that the forests are under an urgent need of reforestation

\subsection{Forest Conservation Strategies of Monasteries of EOTC}

According to the result of the interview and PRA, EOTC apply two conservation strategies, namely religious holiness and/or legal protection.

\subsubsection{Religious Holiness}

The main mode of protection is achieved through creating religious commitment and respect among the followers. As the church is believed to be the house of God, everything in the compound is sacred and respected. Every follower is expected to respect and protect the house of God together with the forest enveloping the church. Cutting a tree in the church compound is considered as denying the presence of God unless; it is for the special purpose of the church. It is believed that cutting in and smuggling of trees from the church compound would bring a misery and the one who did it is considered as a person who has violated the Kingdom of God and would be isolated from the church communities. A person that cuts atree or even a dead branch for personal use would be presented to the church community / church scholars and asked to repent and be committed not to repeat the mistake again. If the person fails to admit his/her mistake voluntarily $\mathrm{He} /$ she would be alienated from the church community which is said to be 'Gizit'. Hence, since Orthodox Christians fear such conditions and protects the trees in church forests. 


\subsubsection{Legal Protection Methods}

Monastery forest resources are found around people of different attitudes and perspectives of which force to use guards and civil law to conserve and protect their forest resources. At present the demand forest product is increasing the encroachers and outlaws destruct the forest. Therefore, EOTC assigned guards to prevent such conditions before it happens and to bring to the civil courts for the appropriate measures.

\section{Conclusion}

Religion and cultural practices have contributed in the conservation of resources through the ascription of spiritual powers to soil, water, forest and etc.

Monastery and church forests are very important repositories for both faunal and floral resources of Ethiopia, especially for endangered and endemic species as sources of germplasm particularly of tree seeds for the conservation of these species. They are indicators of species to be selected for conservation programs in their respective localities. In regions where the original vegetation cover has gone, the islands of monastery and/or church forests are indicators of the Agroecological Zones and of past natural vegetation.

Monastery and/or church forests are excellent centres of learning and research. They are ideal sites for studies on vegetation history, ecology, taxonomy and other fields of biology and forestry. In situ forest conservation sites can be established in several of the monastery forests. Monastery and church forests are sources of knowledge on biodiversity including its uses. Moreover, they could serve as models of sustainable forest management with a minimum amount of human intervention.

Monastery forests are under severe threat and are declining in their regenerating potentials. Conservtion of monastery forests by the churches becoming beyond its capacity to save them from the pressure of the local people for agricultural land expansion, grazing and destructive timber production. The issue of ownership aggravated the rate of deforestation as the surrounding people. The Ethiopian Orthodox Tewahido Church should be entitled of its forests. This may require the recognition of monastery and church forests as one of the forest ownership categories by the government. Anthropogenic pressure is byfar the most devastating challenges in the conservation of monastery forest. The traditional concept of forest conservation is in need of shift to a new concept of forest genetic resource conservation and the customary practices are also in need of modification with advanced technologies as well.

To prevent the loss of invaluable biological and natural resources, a rescue operation should be launched by all concerned bodies and the intervention of the Ethiopian government is crucial to save the remaining monastery and church forests. In situ conservation sites should be delineated and managed in appropriate monastery / church forests and seeds of threatened species should be collected for ex situ conservation measures.

Research institutes, IBC, Debre Birhan University, Forest research center, Amhara forest enterprise, and Agriculture and Natural resource conservation experts need to be integrated to use the accumulated forest conservation practice, knowledge and germplasms. Further studies are recommended in other aspects of monastery and church forests.

\section{Appendix}

Appendix 1. List of plant species collected from selected monasteries of North Shewa.

\begin{tabular}{|c|c|c|c|c|}
\hline № & Scientific Name & Family & Ha & Local name(Am) \\
\hline 1 & Acacia abyssinica Hochst.exBenth. & Fabaceae & $\mathrm{T}$ & Bazragirar \\
\hline 5 & Acokanthera schimperi & Apocynaceae & $\mathrm{T}$ & Merenz \\
\hline 2 & Albizia schimperiana & Fabaceae & $\mathrm{T}$ & Sessa \\
\hline 3 & Allophylus abyssinicus & Anacardiaceae & $\mathrm{T}$ & Embis \\
\hline 6 & Apodytes dimidiata E.Mey.ex.Arn & Icacinaceae & $\mathrm{T}$ & Donga \\
\hline 7 & Arundinaria alpina K. Schum & Poaceae & $\mathrm{T} / \mathrm{S}$ & Kerkeha \\
\hline 8 & Asparagus africanus Lam. & Asparagaceae & $\mathrm{S}$ & Sriti \\
\hline 9 & Balanites aegyptiaca & Balanitaceae & $\mathrm{T}$ & Bedeno \\
\hline 10 & Bersama abyssinica Fresen. & Melianthaceae & $\mathrm{S}$ & Azamir \\
\hline 11 & Buddleja polystachya Fresen. & Loganiaceae & $\mathrm{T}$ & Anfar \\
\hline 12 & Calpurnia aurea(Ait.) Benth. & Fabaceae & $\mathrm{S}$ & Digita \\
\hline 14 & Capparis tomentosa & Capparidaceae & $\mathrm{T}$ & Gumero \\
\hline 13 & Carissa spinarum $L$. & Apocynaceae & $\mathrm{S}$ & Agam \\
\hline 15 & Celtis Africana & Ulmaceae & $\mathrm{T}$ & Kawoot \\
\hline 17 & Clematis simensis Perr. And Guill. & Ranunculaceae & $\mathrm{C}$ & Azohareg \\
\hline 18 & Clerodendrum myricoides Vatke. & Lamiaceae & $\mathrm{S}$ & Misirch \\
\hline 19 & Clutia lanceolataForssk. & Euphorbiaceae & $\mathrm{S}$ & Fiyelefej \\
\hline 20 & Cordia Africana & Boraginaceae & $\mathrm{T}$ & Wanza \\
\hline 21 & Crotalaria laburnifolia $L$. & Fabaceae & $\mathrm{S}$ & $\mathrm{x}$ \\
\hline
\end{tabular}




\begin{tabular}{|c|c|c|c|c|}
\hline № & Scientific Name & Family & Ha & Local name(Am) \\
\hline 22 & Crotalaria mildbraedii Bak.f & Fabaceae & $\mathrm{S}$ & $\mathrm{x}$ \\
\hline 23 & Croton macrostachyus Del. & Euphorbiaceae & $\mathrm{T}$ & Etsezewie \\
\hline 24 & Cupressuslusitanica Mill. & Cupressaceae & $\mathrm{T}$ & Yeferenjitsid \\
\hline 25 & Cyathula uncinulata(Schrad) & Amaranthaceae & $\mathrm{S}$ & $\mathrm{x}$ \\
\hline 26 & Discopodium penninervium Hochst. & Solanaceae & $\mathrm{S}$ & Ameraro \\
\hline 93 & Dodonaea angustifolia & Sapindaceae & $\mathrm{T} / \mathrm{Sh}$ & Kitkita \\
\hline 27 & Dombeya torrida(J.F. Gmel) P. Bamps & Sterculiaceae & $\mathrm{T} / \mathrm{S}$ & Wolikfa \\
\hline 28 & Dovyalis abyssinica Warb. & Flacourtiaceae & $\mathrm{S}$ & Koshim \\
\hline 29 & Dracaena steudneri & Boraginaceae & $\mathrm{T}$ & Etsepatos \\
\hline 30 & Ekebergia capensis Sparrm. & Meliaceae & $\mathrm{T}$ & Lol \\
\hline 31 & Erica arborea $L$. & Ericaceae & $\mathrm{S}$ & Asta \\
\hline 90 & Eucalyptus camaldulensis & Myrtaceae & $\mathrm{T}$ & Key bahirzaf \\
\hline 32 & Eucalyptus globules Labill. & Myrtaceae & $\mathrm{T}$ & Nech Bahir zaf \\
\hline 91 & Eucalyptus globulos & Myrtaceae & $\mathrm{T}$ & Nechi bahirzaf \\
\hline 33 & Euclea schimperi & Ebenaceae & $\mathrm{S}$ & Dedeho \\
\hline 34 & Euphorbia abyssinica & Euphorbiaceae & $\mathrm{T}$ & Kulkual \\
\hline 94 & Euphorbia tirucalli & Euphorbiaceae & $\mathrm{S}$ & Kulkual \\
\hline 35 & Ficus surForssk. & Moraceae & $\mathrm{T}$ & Shola \\
\hline 36 & Ficus vasta & Moraceae & $\mathrm{T}$ & Warika \\
\hline 37 & Galiniera saxifrage & Rubiaceae & $\mathrm{T}$ & Yetotakula \\
\hline 38 & Grewia ferruginea & Tiliaceae & $\mathrm{T}$ & Lenkoata \\
\hline 39 & Hagenia abyssinica J.F.Gmel. & Rosaceae & $\mathrm{T}$ & Kosso \\
\hline 40 & Halleria lucida $L$. & Scrophulariaceae & $\mathrm{T} / \mathrm{S}$ & Masinkero \\
\hline 41 & Hypericum revolutumVahl. & Hypericaceae & $\mathrm{S}$ & Amija \\
\hline 42 & Inula confertiflora A. Rich. & Asteraceae & $\mathrm{H}$ & Weinagift \\
\hline 43 & Jasminum abyssinicum Hochst.ex DC. & Oleaceae & $\mathrm{Li} / \mathrm{C}$ & Tenbelel \\
\hline 44 & Juniperus procera Hochst ex Endl. & Cupressaceae & $\mathrm{T}$ & Tsid \\
\hline 45 & Justitia schimperiana(Hochst ex Nees) T.Anders. & Acanthaceae & $\mathrm{S}$ & Simyiza \\
\hline 46 & Leucas stachydiformis. Briq. & Lamiaceae & $\mathrm{S}$ & Limich \\
\hline 47 & Lippia adoensis Hochst .ex Walp & Lamiaceae & $\mathrm{S}$ & Kesie \\
\hline 48 & Maesa lanceolata Forssk. & Myrsinaceae & $\mathrm{T} / \mathrm{S}$ & Abeye \\
\hline 50 & Maytenus arbutifolia( A.Rich.) Wilczek & Celastraceae & $\mathrm{T} / \mathrm{S}$ & Atat \\
\hline 51 & Maytenus obscura(A.Rich.) Cuf. & Celastraceae & $\mathrm{T}$ & Kumbel \\
\hline 54 & Myrica salicifolia Hochstex.A.Rich. & Myricaceae & $\mathrm{T}$ & Kelewa \\
\hline 55 & Myrsine africana $L$. & Myrsinaceae & $\mathrm{S}$ & Kechemo \\
\hline 56 & Nuxia congesta R. Br. Ex Fresen. & Loganiaceae & $\mathrm{T} / \mathrm{S}$ & Anfar \\
\hline 57 & Ocimum lamiifolium Hochst. exBenth. & Lamiaceae & $\mathrm{S}$ & Damakesie \\
\hline 58 & Olea capensis & Oleaceae & $\mathrm{T}$ & Damot weira \\
\hline 59 & Olea europaea subsp. Cuspidata Wall.ex.G.Don. & Oleaceae & $\mathrm{T}$ & Weira \\
\hline 61 & Olinia rochetiana A. Juss. & Oliniaceae & $\mathrm{T}$ & Tifie \\
\hline 62 & Opuntiaficus-indica (L.) Miller & Cactaceae & $\mathrm{S}$ & Beles \\
\hline 63 & Osyris quadripartitaDecn. & Santalaceae & $\mathrm{S}$ & Keret \\
\hline 64 & Periploca linearifoliaA. Rich \& Quart.-Dill. & Asclepiadaceae & $\mathrm{L}$ & $\mathrm{x}$ \\
\hline 65 & Phoenix reclinata & Arecaceae & $\mathrm{T}$ & Selen/zenbaba \\
\hline 66 & Phytolacca dodecandra L "Herit & Phytolaccaceae & $\mathrm{Li} / \mathrm{C}$ & Endod \\
\hline 67 & Pinus patulaD.Don. & Pinaceae & $\mathrm{T}$ & Pachula \\
\hline 68 & Pittosporum viridiflorumSims & Pittosporaceae & $\mathrm{T}$ & Weil \\
\hline 69 & Podocarpus falcatus (Thunb.) Mirb. & Podocarpaceae & $\mathrm{T}$ & Zigiba \\
\hline 16 & Premna schimperi & verbenaceae & $\mathrm{T}$ & Chocho \\
\hline 70 & Prunus africana (Hook.f) Kalkm & Rosaceae & $\mathrm{T}$ & Tikurenchet \\
\hline 71 & Rhamnus prinoidesLHer. & Rhamnaceae & $\mathrm{S}$ & Giesho \\
\hline 72 & Rhamnus staddoA.Rich. & Rhamnaceae & $\mathrm{S}$ & Tsedo \\
\hline
\end{tabular}




\begin{tabular}{lllll}
\hline No & Scientific Name & Family & Ha & Local name(Am) \\
\hline 74 & Rhus glutinosaGilbert & Anacardiaceae & $\mathrm{T}$ & Tilem/talo \\
73 & Rhus vulgarisMeikle & Anacardiaceae & $\mathrm{T}$ & Kimo \\
75 & Ricinus comminus L. & Euphorbiaceae & $\mathrm{S}$ & Gulo \\
76 & Rosa abyssinica Lindley & Rosaceae & $\mathrm{S}$ & Kega \\
77 & Rubus steudneriSchweinf. & Rosaceae & $\mathrm{C}$ & Enjori \\
78 & Rubus volkensiiEngl. & Rosaceae & $\mathrm{C}$ & Enjori \\
79 & Rumex nervosus Vahl & Polygonaceae & $\mathrm{S}$ & Embuacho \\
80 & Salix subserrata & Salicaceae & $\mathrm{T}$ & Wonzadmik/akaya \\
82 & Sideroxylon oxyacanthum Baill. & Sapotaceae & $\mathrm{S}$ & x \\
81 & Solanecio gigas & Asteraceae & $\mathrm{H}$ & shikokogomen \\
83 & Sparmannia ricinocarpa (Eckl. \& Zeyh) O.Ktze & Tiliaceae & $\mathrm{H}$ & Welikifa \\
84 & Stephania abyssinica (Dill. Rich.) Walp. & Menispermaceae & Li/C & Ayithareg \\
96 & Syzygium guineense & Myrtaceae & $\mathrm{T}$ & Dokima \\
95 & Terminalia brownii & Combretaceae & $\mathrm{T} / \mathrm{Sh}$ & Abalo/weyba \\
85 & Thymus schimperi Ronniger & Lamiaceae & $\mathrm{H}$ & Tosign \\
86 & Urera hypselodendron(A.Rich.) Weed. & Urticaceae & Li/C & Lankuso \\
60 & Vernonia amygdalinaDel. & Asteraceae & $\mathrm{T}$ & Girawa \\
88 & Vitis vinifera & Vitaceae & Li/C & Wein \\
89 & Zehneria scabra & Cucurbitaceae & $\mathrm{H}$ & Etse sabek \\
92 & Ziziphus mucronata & Rhamnaceae & $\mathrm{T}$ & Geba/kurkura \\
\hline
\end{tabular}

Key: $(\mathrm{Ha}=$ habit, $\mathrm{T}=$ tree, $\mathrm{S}=$ shrub, $\mathrm{T} / \mathrm{S}=$ tree/shrub, $\mathrm{C}=$ climber, $\mathrm{SCs}=$ scandent shrub, $\mathrm{L}=\mathrm{Liana}, \mathrm{E}=$ epiphyte, Am=Amharic, and $\mathrm{F}=$ fern).

\section{References}

[1] Abeje Eshete, Demel Teketay and Hulten, H. H. (2005). The Socio-Economic Importance and Status of Populations of Boswellia papyrifera (Del.) Hochst in Northern Ethiopia: The Case of North Gondar Zone. Forests Trees and Livelihoods 15: 55-74.

[2] Alemayehu Wasie (2002). Opportunities, Constraints and Prospects of Ethiopian Orthodox Tewahido Churches in Conserving Forest Resources: The Case of Churches in South Gonder,Northern Ethiopia. MSc thesis, Swedish University of Agricultural Sciences, Skinnskatterberg, Sweden.

[3] Alemayehu Wasie, Demel Teketay and N. Powell (2005). Church forests in North Gondor Administrative Zone, Northern Ethiopia. Forests, Trees and Livelihood 15(4): 349-374.

[4] Aymro Wondmagegnehu and Motovu, J., (1970). The Ethiopian Orthodox Church. The Ethiopian Orthodox Mission, Addis Ababa, Ethiopia.

[5] Azene Bekele, (1993). Useful trees and shrubs for Ethiopia: Identification, Propagation and Management for Agricultural and Pastoral Communities.

[6] Bahru Zewde, (1997). The Forests of WalloIn Historical perspective: With a Focus on the Yagof State forest. Paper prepared for the Conference on "Environmental and Development" Debre Zeit, 12-14 June 1997.

[7] Cunningham, A.B. (2001). Applied Ethnobotany: People, wild plant use and conservation. Earthscan, London.

[8] Dagnachew Gebeyehu, (2001). Sampling strategy for assessment of woody plant species diversity: a study in Tara Gedam natural forest, Ethiopia. MSc. Thesis submitted to Swedish University of Agricultural Science.
[9] Demel Teketay, (1997). Seedling population and regeneration of woody species in dry Afromontane forests of Ethiopia. Forest Ecology and Management 98 (1997), 149-165.

[10] Dereje Denu (2007). Floristic composition and ecological study of Bibita forest (Gurda Farda), Oromia National Regional State, west Ethiopia. Unpublished M.Sc Thesis, Addis Ababa University, Addis Ababa.

[11] Elias Endale (2003). Socio-economic data of Agriculture and Natural Resource, Agricultural Development, Gamo Gofa Zone of SNNP.

[12] Getahun Kassa, Eskinder Yigezu (2015). Women Economic Empowerment through Non Timber Forest Products in Gimbo District, South West Ethiopia. American Journal of Agriculture and Forestry. Vol. 3, No. 3, 2015, pp. 99-104. doi: 10.11648/j.ajaf.20150303.16

[13] Gadgil, M., and Vartak, V.D., (1976). The sacred groves of Western Ghats in India. Economic Botany 30:152-160.

[14] Kent, M. and Coker, p., (1992). Vegetation Description and Analysis: A Practical Approach. Belwill haven press,London.

[15] Martin, G. J. (1995). Ethnobotany: A Methods Manual. Chapman and Hall, London.

[16] Muller-Dombis, D. and Ellenberg, H. (1974). Aims and Methods of Vegetation Ecology, John Wiley and Sons. Inc. New York. pp 547.

[17] Muluken Mekuyie Fenta (20140. Human-Wildlife Conflicts: Case Study in Wondo Genet District, Southern Ethiopia. Agriculture, Forestry and Fisheries. Vol. 3, No. 5, 2014, pp. 352-362. doi: 10.11648/j.aff.20140305.14

[18] Mwendera, E.J. and M.A. Mohamed Saleem (1997). Hydrologic response to cattle grazing in the Ethiopian highlands. Agriculture, Ecosystems and Environment 64: 33-41. 
[19] Siboniso M. Mavuso, Absalom M. Manyatsi, Bruce R. T. Vilane(2015). Climate Change Impacts, Adaptation and Coping Strategies at Malindza, a Rural Semi-Arid Area in Swaziland. American Journal of Agriculture and Forestry. Vol. 3, No. 3, 2015, pp. 86-92. doi: 10.11648/j.ajaf.20150303.14

[20] Tadesse Woldemariam (1998). Diversity of Woody Plants and Avifauna in a Dry Afromontane Forest, On the Central Plateau of Ethiopia. SLU: Ethiopian MSc in Forestry Program thesis work.

[21] Taye Bekele, (1998). Biodiversity Conservation: Experience of the Ethiopian Orthodox Tewahido Church, MSc in Forestry Graduates Magazine, 1994-1998.
[22] Yeraswork Admassie(1995). Twenty Years to Nowhere: Property Rights, Land Management and Conservation in Ethiopia. PhD. Dissertation, Uppsala: Uppsala University.

[23] Zelealem Tefera (2001). Common Property Resource Management of an Afro-Alpine Habitat: Supporting a Population of a Critically Endangered Ethiopian Wolf (Canis simensis), Ph.D. Dissertation, Durrel Institute of Conservation and Ecology, University of Kent, Canterbury.

[24] Zewge Teklehaimanot (2001). Biodiversity conservation in ancient church and monastery yards in Ethiopia. 